\title{
Pharmacokinetics and pharmacodynamics of anti-infective agents during continuous veno-venous hemofiltration in critically ill patients: Lessons learned from an ancillary study of the IVOIRE trial
}

Dominique Breilh ${ }^{1}$, Patrick M. Honore ${ }^{2}$, David De Bels ${ }^{2}$, Jason A. Roberts ${ }^{3}$, Jean Baptiste Gordien ${ }^{1}$, Catherine Fleureau ${ }^{4}$, Antoine Dewitte ${ }^{4}$, Julien Coquin ${ }^{4}$, Hadrien Rozé $^{4}$, Paul Perez ${ }^{5}$, Rachid Attou ${ }^{2}$, Sebastien Redant ${ }^{2}$, Luc Kugener ${ }^{2}$, Marie-Claude Saux $^{1}$, Herbert D. Spapen ${ }^{6}$, Alexandre Ouattara ${ }^{4,7}$, Olivier Joannes-Boyau ${ }^{4}$ on behalf of the IVOIRE study group

'Laboratory of Clinical Pharmacokinetics and Clinical Pharmacy, INSERM U1034, Haut-Lévêque Hospital, CHU Bordeaux, University of Bordeaux, Segalen, Pessac, France;

IIntensive Care Department, Centre Hospitalier Universitaire Brugmann-Brugmann University Hospital, Brussels, Belgium;

${ }^{3}$ University of Queensland Centre for Clinical Research, Faculty of Medicine \& Centre for Translational Antiinfective Pharmacodynamics, School of Pharmacy, The University of Queensland, Brisbane, Australia; ${ }^{4} \mathrm{CHU}$ Bordeaux, Department of Anaesthesia and Critical Care, Magellan Medico-Surgical Centre, F-33000 Bordeaux, France;

${ }^{5}$ Centre Hospitalier Universitaire de Bordeaux, Pôle de, Santé Publique, Unité de Soutien Méthodologique à la Recherche Clinique et Épidémiologique, France;

${ }^{6}$ Ageing \& Pathology Research Group, Vrije Universiteit Brussel, Brussels, Belgium;

${ }^{7}$ Biology of Cardiovascular Diseases, INSERM, UMR 1034, University of Bordeaux, F-33600 Pessac, France

\section{ABSTRACT}

Background: Hemofiltration rate, changes in blood and ultrafiltration flow, and discrepancies between the prescribed and administered doses strongly influence pharmacokinetics (PK) and pharmacodynamics (PD) of antimicrobial agents during continuous veno-venous hemofiltration $(\mathrm{CVVH})$ in critically ill patients. Methods: Ancillary data were from the prospective multicenter IVOIRE (hlgh VOlume in Intensive caRE) study. High volume (HV, $70 \mathrm{~mL} / \mathrm{kg} / \mathrm{h}$ ) was at random compared with standard volume (SV, $35 \mathrm{~mL} / \mathrm{kg} / \mathrm{h}$ ) CVVH in septic shock patients with acute kidney injury (AKI). PK/PD parameters for all antimicrobial agents used in each patient were studied during five days. Results: Antimicrobial treatment met efficacy targets for both percentage of time above the minimal inhibitory concentration and inhibitory quotient. A significant correlation was observed between the ultrafiltration flow and total systemic clearance (Spearman test: $P<0.005$ ) and between CVVH clearance and drug elimination half-life (Spearman test: $P<0.005$ ). All agents were easily filtered. Mean sieving coefficient ranged from $38.7 \%$ to $96.7 \%$. Mean elimination half-life of all agents was significantly shorter during HV-CVVH (from 1.29 to $28.54 \mathrm{~h}$ ) than during SV-CVVH (from 1.51 to $33.85 \mathrm{~h}$ ) $(P<$ 0.05). Conclusions:This study confirms that CVVH influences the PK/PD behavior of most antimicrobial agents. Antimicrobial elimination was directly correlated with convection rate. Current antimicrobial dose recommendations will expose patients to underdosing and increase the risk for treatment failure and development of resistance. Dose recommendations are proposed for some major antibiotic and antifungal treatments in patients receiving at least 25 $\mathrm{mL} / \mathrm{kg} / \mathrm{h}$ CVVH.

Key words: pharmacokinetics, pharmacodynamics, continuous veno-venous hemofiltration, high volume hemofiltration, septic shock, antibiotics, antibiotic dosage 
Breilh et al.: Pharmacokinetics and pharmacodynamics of anti-infective agents

\section{INTRODUCTION}

Adequate antimicrobial therapy is essential to maximize the survival of critically ill patients. ${ }^{[1]}$ Anti-infective drugs are classified as time-dependent (e.g., $\beta$-lactams, carbapenems, macrolides, fluconazole, vancomycin) when their bactericidal effect depends on the time that plasma levels remain above a threshold minimal inhibitory concentration (MIC), or concentration-dependent (e.g., aminoglycosides, fluoroquinolones, echinocandins, daptomycin, polyenes, doxycyclin) when the height of peak concentration above the MIC determines the killing effect. ${ }^{[2]}$ Acute kidney injury (AKI) significantly interferes with the administration of anti-infective agents. Antibacterial pharmacokinetics (PK) are affected by AKI itself, the underlying or accompanying disease process, and the applied renal replacement therapy. Continuous renal replacement therapy (CRRT) causes alterations in drug clearance. Factors influencing PK and pharmacodynamics (PD) of antimicrobial drugs during CRRT include the CRRT mode (diffusion, convection, or both), changes in blood and ultrafiltration flow, type of filtration membrane (e.g., highly adsorptive filters), and discrepancies between prescribed and actually administered antimicrobial dose. For these reasons, drug dose adjustment in critically ill patients receiving CRRT is challenging. ${ }^{[3,4,5]}$

Continuous veno-venous hemofiltration (CVVH) is the most commonly used CRRT technique in the critical care setting. ${ }^{[5]}$ Antimicrobial drug behavior during CVVH is still scarcely documented. This is of concern because higher ultrafiltrate doses are increasingly promoted. ${ }^{[7,8,9]}$. Moreover, great divergence exist between predicted and observed removal of antibiotics in critically ill CVVHtreated patients. ${ }^{[10]}$

We applied the established $\mathrm{PK} / \mathrm{PD}$ principles in a subgroup of patients from the previously published IVOIRE trial, which compared high volume (HV; $70 \mathrm{~mL} / \mathrm{kg} / \mathrm{h})$ with standard volume (SV; $35 \mathrm{~mL} / \mathrm{kg} / \mathrm{h}) \mathrm{CVVH}$ in septic shock patients with AKI. ${ }^{[11]}$ Importantly, the IVOIRE trial was conceived in 2004 when PK/PD knowledge was still in its infancy. At that time, no consensus existed regarding antimicrobial dosing during HV-CVVH. Also, the primary endpoint of the IVOIRE study was comparing the 28-day mortality between the patients treated with HV-CVVH and SV-CVVH. Therefore, upfront use of higher antimicrobial doses in the HV-CVVH group was not supported because it was thought to produce substantial outcome bias. It was decided to administer all drugs according to the accepted dose recommendations at that time (i.e., weight-adapted, as in patients without AKI) and to treat both SV-CVVH and HV-CVVH patients with comparable doses of antimicrobials either in continuous or intermittent infusion.
The current study is aimed to assess whether a different convection rate determines antimicrobial PK behavior during CVVH. The study results also allowed to create dose recommendations for some of the most commonly used antimicrobials in critically ill patients receiving a CVVH dose of at least $25 \mathrm{~mL} / \mathrm{kg} / \mathrm{h}$.

\section{PATIENTS AND METHODS}

\section{Patients}

PK/PD parameters of all administered antimicrobial agents were evaluated in a subgroup of patients who completed a $96 \mathrm{~h}$ therapy within the scope of the IVOIRE study. All observations were made abiding the standard routine patient care incorporated within the IVOIRE study protocol. ${ }^{[1]]}$ The Institutional Ethical Committee waived a formal approval procedure.

\section{Hemofiltration Technique}

A $14 \mathrm{~F}$ coaxial double lumen hemofiltration catheter was inserted either in the right internal jugular vein or in the femoral veins. CVVH was performed using an Aquarius ${ }^{\circledR}$ hemofiltration circuit (Edwards Life Sciences), with a $1.9 \mathrm{~m}^{2}$ Aquamax ${ }^{\circledR}$ polyethersulfone filter (Edwards Life Sciences). Since this filter is non-adsorptive, antibiotic elimination is determined by ultrafiltration alone. Hemofiltration treatment was initiated according to randomization towards either SVCVVH or HV-CVVH. Blood flow rate was adapted to obtain a filtration fraction $\leq 25 \%$. Anticoagulation was ensured by non-fractionated heparin. Filters were changed every $48 \mathrm{~h}$ or in case of early clotting. Substitution was divided in a $1 / 3-2 / 3$ proportion between pre- and post-dilution. Patients who still required CVVH at the end of the study were continued on standard hemofiltration at $35 \mathrm{~mL} / \mathrm{kg} / \mathrm{h}$.

\section{Sample collection}

Mass-transfer concept was used to evaluate the concentration of cleared and absorbed antimicrobials. Indicative samples were taken after 12 or $24 \mathrm{~h}$ PK steady-state. Five samples were collected in both groups (at H1 [i.e., $1 \mathrm{~h}$ after antimicrobial infusion], H3, H6, H9 and at $\mathrm{H} 12$ or H24). Three samples were taken for each time period, one from the venous line after the filter, one from the effluent bag and one from the patient's arterial catheter. As predilution was used, sampling before the filter was not applied. Time and total effluent volume in the bags were recorded for each sample. All plasma and ultrafiltrate samples were placed in $5 \mathrm{ml}$ Vacutainer tubes and immediately centrifuged and frozen at $-80^{\circ} \mathrm{C}$ until assayed.

\section{Sample assays}

Plasma and ultrafiltrate concentrations of anti-infective agents were determined with reversed-phase highperformance liquid chromatography (HPLC) using an 
Breilh et al.: Pharmacokinetics and pharmacodynamics of anti-infective agents

\begin{tabular}{|c|c|c|c|}
\hline Demographic data & All & HV & LV \\
\hline Age (years) & $66 \pm 12$ & $69 \pm 9$ & $63 \pm 14$ \\
\hline Height (cm) & $169 \pm 10$ & $170 \pm 8$ & $167 \pm 12$ \\
\hline Weight (kg) & $75 \pm 18$ & $77 \pm 22$ & $73 \pm 13$ \\
\hline Gender (M/F) & $28 / 14$ & $15 / 7$ & $13 / 7$ \\
\hline SAPS 2 & $63 \pm 10$ & $65 \pm 8$ & $61 \pm 12$ \\
\hline SOFA & $12 \pm 2$ & $12 \pm 2$ & $12 \pm 2$ \\
\hline Protein & $45 \pm 8$ & $45 \pm 8$ & $46 \pm 9$ \\
\hline Albumin & $21 \pm 4$ & $21 \pm 4$ & $22 \pm 3$ \\
\hline Creatinine & $243 \pm 116$ & $278 \pm 128$ & $196 \pm 82$ \\
\hline Pathology & 42 & 22 & 20 \\
\hline Peritonitis & 26 & 15 & 11 \\
\hline Sepsis & 3 & 1 & 2 \\
\hline Mediastinitis & 4 & 2 & 2 \\
\hline Pneumonia & 4 & 1 & 3 \\
\hline Endocarditis & 5 & 3 & 2 \\
\hline Urine output (24 h) & $223 \pm 167$ & $195 \pm 166$ & $253 \pm 167$ \\
\hline Blood flow rate $(\mathrm{mL} / \mathrm{min})$ & $278 \pm 51$ & $317 \pm 37$ & $234 \pm 18$ \\
\hline Ultrafiltration rate $(\mathrm{mL} / \mathrm{h})$ & $3956 \pm 1602$ & $5221 \pm 1137$ & $2557 \pm 433$ \\
\hline 28-day mortality & 15 & 8 & 7 \\
\hline
\end{tabular}

HV: High volume; LV: Low volume.

adapted ultraviolet (UV) detection method. ${ }^{[13-15]}$ Plasma samples were extracted by SPE? with Phenomenex Strata- $\mathrm{X}^{\mathrm{TM}}$ or Varian Plexa ${ }^{\mathrm{TM}}$ cartridges (for azoles) or ultra-filtered with Microcon ${ }^{\mathrm{TM}}$ devices. Dialysate/ ultrafiltrate samples underwent no extraction but were directly injected into the system. Chromatographic separation was performed on Prontosil AQ+ $150 \mathrm{x}$ $4.6 \mathrm{~mm} 5 \mu \mathrm{m}$ columns (Bischoff), or on a Gemini C6phenyl $150 \times 4.6 \mathrm{~mm} 5 \mu \mathrm{m}$ column (Phenomenex) for azoles. Mobile phases used phosphate buffers (at $\mathrm{pH}$ between 3.5 and 7) and acetonitrile. TEA 0.04\% at $\mathrm{pH} 2.7$ replaced phosphate buffer for piperacilline/ tazobactam and ofloxacin. Wavelengths between 210 and $320 \mathrm{~nm}$ were used for UV detection. All HPLC methods were validated according to bioanalytical FDA criteria. ${ }^{[16]}$ Linezolid, imipenem, and ertapenem were used as an internal standard. Coefficients of determination $\left(r^{2}\right)$ for the plasma assays over the standard curves concentration ranges were all above 0.99 with intercept close to zero for all studies. Within- and between-day coefficients of variation $(\mathrm{CV})$ for plasma samples ranged respectively from $0.84 \%$ to $2.52 \%$ and from $1.36 \%$ to $5.43 \%$ at the chosen quality control concentrations. Coefficients of variation $\left(r^{2}\right)$ for the ultrafiltrate assays over the standard curves concentration ranges were all above 0.99 and intercept close to zero for all studies. Here, within- and between-day CV for ultrafiltrate samples ranged respectively from $0.78 \%$ to $2.43 \%$ and from $1.08 \%$ to $4.86 \%$ at the chosen quality control concentrations. Within- and between-day accuracy for the plasma and ultrafiltrate assays ranged respectively from $96.23 \%$ to $104.32 \%$ and from $98.24 \%$ to $102.68 \%$. All assays had good sensitivity. Limit of detection (LOD) and limit of quantification (LOQ) were under minimal concentrations measured on patients. All HPLC assay parameters are summarized in Table 2.

\section{Pharmacokinetic analysis}

Plasma concentration-time data for all anti-infective agents were analyzed by standard PK methods using Kinetica ${ }^{\mathrm{TM}}$ software and an open one-compartmental model with first order elimination (Kinetica ${ }^{\mathrm{TM}}$ version 4.4 for Windows, San Diego, CA). Pre-membrane plasma drug concentrations were used to determine the PK parameters. The apparent terminal elimination rate constant $\left(k_{\mathrm{e}}\right)$ was assessed by least-squares regression analysis of the terminal portion of the natural log concentration-time curve. Elimination half-life $\left(t_{1 / 2}\right)$ was calculated as $0.693 / k_{\mathrm{el}}$. Maximum plasma drug concentration $\left(C_{\max }\right)$ was obtained at the end of the drug infusion. Minimum plasma concentration $\left(C_{\min }\right)$ was determined by direct measurement at the end of the dosing interval. Steady-state concentration $\left(\mathrm{C}_{\mathrm{ss}}\right)$ was determined at PK steady-state during continuous infusion. The area 
Breilh et al.: Pharmacokinetics and pharmacodynamics of anti-infective agents

\begin{tabular}{|c|c|c|c|c|c|c|c|}
\hline & Column & Mobile phase & $\begin{array}{l}\lambda \\
(\mathrm{nm})\end{array}$ & $\begin{array}{l}\text { Plasma } \\
\text { extraction }\end{array}$ & $\begin{array}{l}\text { LOD } \\
(\mu \mathrm{g} / \mathrm{mL})\end{array}$ & $\begin{array}{l}\text { LOQ } \\
(\mu \mathrm{g} / \mathrm{mL})\end{array}$ & $\begin{array}{l}\text { Volume injected } \\
(\mu L)\end{array}$ \\
\hline Ertapenem & Prontosil AQ+ & $\begin{array}{l}\mathrm{Na}_{2} \mathrm{HPO}_{4} \\
\mathrm{pH}=6.5 / \mathrm{ACN} v / \mathrm{v}\end{array}$ & 305 & $\begin{array}{l}\text { Ultrafiltration } \\
\text { Microcon } \mathrm{YM} 10^{\mathrm{TM}}\end{array}$ & 0.05 & 0.25 & 40 \\
\hline Imipenem & Prontosil AO + & $\begin{array}{l}\mathrm{Na}_{2} \mathrm{HPO}_{4} \\
\mathrm{pH}=6.5 / \mathrm{ACN} v / \mathrm{v}\end{array}$ & 305 & $\begin{array}{l}\text { Ultrafiltration } \\
\text { Microcon } \mathrm{YM} 10^{\mathrm{TM}}\end{array}$ & 0.04 & 0.20 & 40 \\
\hline Doripenem & Prontosil AQ + & $\begin{array}{l}\mathrm{Na}_{2} \mathrm{HPO}_{4} \\
\mathrm{pH}=6.5 / \mathrm{ACN} v / \mathrm{v}\end{array}$ & 305 & $\begin{array}{l}\text { Ultrafiltration } \\
\text { Microcon } \mathrm{YM} 10^{\mathrm{TM}}\end{array}$ & 0.05 & 0.25 & 40 \\
\hline Ceftriaxone & Prontosil AQ + & $\begin{array}{l}\mathrm{Na}_{2} \mathrm{HPO}_{4} \\
\mathrm{pH}=7 / \mathrm{ACN} v / \mathrm{v}\end{array}$ & 272 & $\begin{array}{l}\text { SPE } \\
\text { Strata- } X^{\mathrm{TM}}\end{array}$ & 0.05 & 0.25 & 20 \\
\hline $\begin{array}{l}\text { Piperacilline } \\
\text { /Tazobactam }\end{array}$ & Prontosil AO + & $\begin{array}{l}\text { TEA } 0,04 \% \\
\mathrm{pH}=2.7 / \mathrm{ACN} v / \mathrm{v}\end{array}$ & 210 & $\begin{array}{l}\text { SPE } \\
\text { Strata- } X^{\mathrm{TM}}\end{array}$ & 0.15 & 0.50 & 10 \\
\hline Ofloxacine & Prontosil AQ + & $\begin{array}{l}\text { TEA } 0,04 \% \\
\mathrm{pH}=2.7 / \mathrm{ACN} v / \mathrm{v}\end{array}$ & 295 & $\begin{array}{l}\text { SPE } \\
\text { Strata- } X^{\mathrm{TM}}\end{array}$ & 0.03 & 0.15 & 20 \\
\hline Linezolid & Prontosil AQ + & $\begin{array}{l}\mathrm{KH}_{2} \mathrm{PO}_{4} \\
\mathrm{pH}=3.5 / \mathrm{ACN} v / \mathrm{v}\end{array}$ & 255 & $\begin{array}{l}\text { SPE } \\
\text { Strata- } X^{m}\end{array}$ & 0.25 & 0.75 & 20 \\
\hline Daptomycine & Prontosil AQ + & $\begin{array}{l}\mathrm{Na}_{2} \mathrm{HPO}_{4} \\
\mathrm{pH}=5.5 / \mathrm{ACN} v / \mathrm{v}\end{array}$ & 210 & $\begin{array}{l}\text { SPE } \\
\text { Strata- } X^{\mathrm{TM}}\end{array}$ & 0.15 & 0.50 & 20 \\
\hline Metronidazole & Prontosil AQ + & $\begin{array}{l}\mathrm{Na}_{2} \mathrm{HPO}_{4} \\
\mathrm{pH}=7 / \mathrm{ACN} v / \mathrm{v}\end{array}$ & 320 & $\begin{array}{l}\text { SPE } \\
\text { Strata- } X^{\mathrm{TM}}\end{array}$ & 0.04 & 0.20 & 20 \\
\hline Fluconazole & $\begin{array}{l}\text { Gemini C6- } \\
\text { phenyl }\end{array}$ & $\begin{array}{l}\mathrm{Na}_{2} \mathrm{HPO}_{4} \\
\mathrm{pH}=7 / \mathrm{ACN} v / \mathrm{v}\end{array}$ & 260 & $\begin{array}{l}\text { SPE } \\
\text { Varian Plexa }\end{array}$ & 0.02 & 0.05 & 25 \\
\hline Voriconazole & $\begin{array}{l}\text { Gemini C6- } \\
\text { phenyl }\end{array}$ & $\begin{array}{l}\mathrm{Na}_{2} \mathrm{HPO}_{4} \\
\mathrm{pH}=7 / \mathrm{ACN} v / \mathrm{v}\end{array}$ & 260 & $\begin{array}{l}\text { SPE } \\
\text { Varian Plexa }{ }^{\mathrm{TM}}\end{array}$ & 0.02 & 0.05 & 25 \\
\hline
\end{tabular}

SPE: Solid phase extraction; ACN: acetonitrile; $\lambda=$ wavelength; LOD: limit of detection; LOQ: limit of quantification.

under the concentration-time curve from time zero to the end of the dosing interval $\left(\mathrm{AUC}_{0-\tau}\right)$ was calculated by the linear trapezoidal summation method. Since true PK steady-state conditions could not be assumed in all patients, volume of distribution $\left(V_{\mathrm{d}}\right)$ was calculated by non-steady-state methods, which take into account the number of doses previously administered. Total systemic clearance $\left(\mathrm{CL}_{\mathrm{S}}\right)$ was calculated by dose $/ \mathrm{AUC}_{0-\tau}$. During $\mathrm{CVVH}$, drugs are predominantly cleared by convection but also in part by membrane adsorption. The sieving coefficient $(\mathrm{Sc})$, the drug concentration in ultrafiltrate, was calculated as $2 \times C_{\mathrm{uf}} /\left(C_{\mathrm{a}}+C_{\mathrm{v}}\right)$, where $C_{\mathrm{uf}}$ is the drug concentration in ultrafiltrate, $C_{\mathrm{a}}$ - the drug concentration in pre-membrane plasma (i.e., plasma obtained from the arterial line in predilution), and $C_{\mathrm{v}}$ - the drug concentration in post-membrane plasma. Clearance of drug across the membrane during $\mathrm{CVVH}\left(\mathrm{CL}_{\mathrm{CVVH}}\right)$ was calculated by $\mathrm{C}_{\mathrm{S}} \times Q_{\mathrm{uf}} \times$ dilution factor (dilution factor $=$ blood flow $(\mathrm{Qb}) /(\mathrm{Qb}+$ predilution flow $(\mathrm{Q} s$ pre $)$ with $\mathrm{Qs}$ pre $=$ volume infused in predilution). The percentage of $\mathrm{CL}_{\mathrm{S}}$ attributed to $\mathrm{CL}_{\mathrm{CVVH}}\left(\% \mathrm{CL}_{\mathrm{S}}\right)$ is calculated as $\left(\mathrm{CL}_{\mathrm{CVVH}} /\right.$ $\left.\mathrm{CL}_{\mathrm{S}}\right) \times 100$. Non-renal clearance $\left(\mathrm{CL}_{\mathrm{NR}}\right)$, which is mainly the residual renal and hepatic clearance, was calculated as $\mathrm{CL}_{\mathrm{S}}-\mathrm{CL}_{\mathrm{CVVH}}$ as urine output in the study population was negligible. All calculations were made by programming PK and CVVH clearance equations into Microsoft Excel 2003 (Microsoft Corporation, Redmond, WA) spreadsheets. Using Excel, measures of central tendency and variability were evaluated for all patient and CVVH characteristics, PK parameters, and CVVH clearance. European Committee on Antimicrobial Susceptibility Testing (EUCAST) breakpoints were used to define micro-organism resistance.

\section{PK/PD analysis}

General PK/PD principles were considered and their clinical application and dosing implications for critically ill patients addressed. The time during which plasma concentrations of free drug are above the minimal inhibitory concentration (MIC) of the infecting pathogen ( $\mathrm{T}>\mathrm{MIC}$ ) was then calculated as natural $\log$ (maximum bacterial population size. $\left.\left(C f u_{\max }\right) / C_{\mathrm{MIC}}\right) / k_{\mathrm{el}}$, where $C_{\mathrm{MIC}}$ is the MIC for the organism. The percent $\mathrm{T} \%>\mathrm{MIC}$ was determined by $(T>\mathrm{MIC} / \tau) \times 100$, where $\tau$ is the dosing interval. Target goal for T\% > MIC was $>40$ to $50 \%$ for 
clinical efficacy and prevention of resistance. The inhibitory quotient (IQ) corresponding to the $\mathrm{C}_{\max } / \mathrm{MIC}$ ratio and the inhibitory area under the curve (AUIC) corresponding to the AUC/MIC ratio were calculated. Target goals for IQ and AUIC were $>4$ and $>125$ respectively for clinical efficacy and prevention of resistance especially for Gramnegative organisms and for concentration-dependent antibiotics. MICs of antibiotics for isolated pathogens were determined by the local clinical microbiology laboratory. Predicted T\% > MIC for dosing regimens not observed in the study patients were calculated based on PK parameters derived from the individual patients within both CVVH groups.

\section{Statistical analysis}

Differences between demographic variables among patients receiving either HV- or SV-CVVH were assessed by oneway analysis of variance fixed-effects model for continuous variables or by two-way chi-square test for categorical variables. Differences among calculated PK parameters were assessed by the two-tailed Mann-Whitney rank sum test for unpaired non-parametric data. Correlations between PK variables were determined using the Spearman's rank correlation coefficient for non-parametric data. All statistical tests were performed with the Statistica ${ }^{{ }^{\mathbf{M}}}$ version 6.1 for Windows (Statistica ${ }^{\mathrm{TM}}$ Software, San Diego, CA). P values $\leq 0.05$ were considered to be significant.

\section{RESULTS}

Forty-five patients were studied for four consecutive days. During this study period, 5 patients received one, 34 patients received two, and 6 patients received three antimicrobial agents. Characteristics of the patients are shown in Table 1. Two patients died in the first few hours of treatment and the samples of one patient were damaged during transportation. Thus, 42 patients were evaluable. Mean arterial plasma and effluent concentrations of the anti-infective agents in both CVVH groups are illustrated in Figure 1. The PK parameters are presented in Tables 3 and 3 bis. All agents were easily filtered. Mean Sc ranged from $38.70 \%$ to $96.70 \%$. Mean $\mathrm{t} 1 / 2$ of all agents during HVCVVH (from 1.29 to $28.54 \mathrm{~h}$ ) was significantly shorter than during SV CVVH (from 1.51 to $33.85 \mathrm{~h})(P<0.05)$. CLs, $\mathrm{CL}_{\mathrm{CVVH}}$ and $\mathrm{CL}_{\mathrm{NR}}$ of all agents were significantly higher during HV-CVVH than during SV-CVVH $(P<0.05)$. Renal excretion of all agents ranged between 13\% and 100\% and $9 \%$ and $57 \%$ for respectively HV- and SV-CVVH. Drug removal was moderate with SV-CVVH but became significantly enhanced by HV-CVVH due to increased ultrafiltrate flow. Drug half-live was extended, probably because of a sepsis-induced Vd increase in most patients. Irrespective of the antimicrobial agent, PK parameters were similar to those observed in infected patients without impaired renal function. The PK/PD parameters (Table 4) demonstrated that treatments met efficiency targets for $\mathrm{T} \%>$ MIC and IQ. Finally, a significant correlation existed between Quf and $\mathrm{CL}_{\mathrm{S}}$ (Spearman test: $P<0.005$ ) and between $\mathrm{CL}_{\mathrm{CVVH}}$ and elimination half-life (Spearman test: $P<0.005)$.

\section{DISCUSSION}

Antimicrobial clearance during CRRT is determined by several chemical drug characteristics. ${ }^{[17]}$ Molecular weight and drug solubility are no limiting factors since antimicrobials are mostly small hydrophilic molecules. ${ }^{[18,19]}$ Drug Vd may increase significantly during resuscitation of septic shock. Thus, extracellular water and by extension current body weight must be considered to optimize the dose of certain antibiotic classes (e.g., aminoglycosides)..$^{[20]}$ Protein binding remains the most important factor limiting antimicrobial elimination by convective CRRT. ${ }^{[21]}$ Proteinbound molecules do not pass the pores of the currently used dialysis membranes. However, protein binding in critically ill patients may be highly variable. An increase in unbound drug will increase Sc and Sd, and hence, clearance by CRRT. ${ }^{[22]}$ Based on the aforementioned, antimicrobial drugs can be categorized as "highly", "moderately" or "not at all" eliminated by CRRT.

Antimicrobial agents have three "killing profiles": timedependent, concentration-dependent, or a combination of both. These profiles determine the drug dosing to obtain maximum therapeutic efficacy at minimal risk for the development of resistance and toxicity. ${ }^{[23]} \mathrm{CL}_{\mathrm{NR}}$ was significantly higher for all agents during $\mathrm{HV}-\mathrm{CVVH}$ as compared with SV-CVVH, which is somewhat unexpected because of the augmented $\mathrm{CL}_{\mathrm{CVVH}}$ in the HV-CVVH group.

\section{Drugs highly influenced by CRRT}

Time-dependent killing

The $\beta$-lactams (penicillins, cephalosporins, carbapenems and monobactams) are small hydrophilic molecules and thus likely to be significantly cleared by CRRT. They exhibit time-dependent killing and have a slow continuous bactericidal effect. Killing is most related to the time during which serum concentration exceeds 1 to 5 times the MIC and, in part, also to a continued suppression of bacterial growth even when drug concentrations fall below MIC (i.e., the post-antibiotic effect). ${ }^{[24]}$ To obtain maximal bactericidal activity, a $\mathrm{T}>\mathrm{MIC}$ of 50 to $60 \%$ is required for penicillins and monobactams, 60 to $70 \%$ for cephalosporins and $40 \%$ for carbapenems.

\section{Piperacillin-tazobactam}

Mueller $e$ al. investigated the PK of piperacillin-tazobactam in anuric patients treated with CVVHD. The elimination 

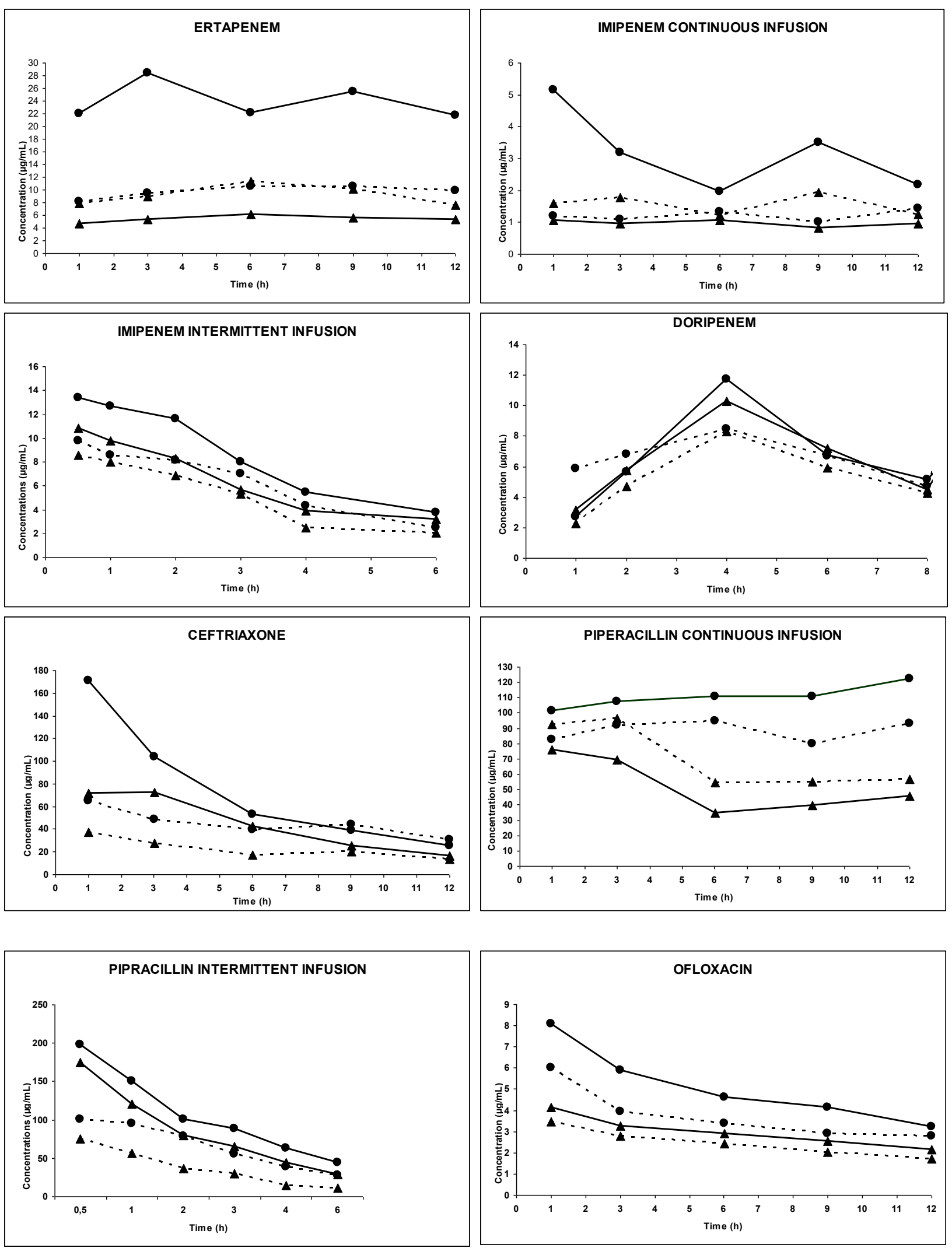

Figure 1: Evolution of arterial plasma concentrations and effluent versus time for anti-infective agents in IVOIRE study during high volume CVVH (HD) and standard volume CVVH (BD) 

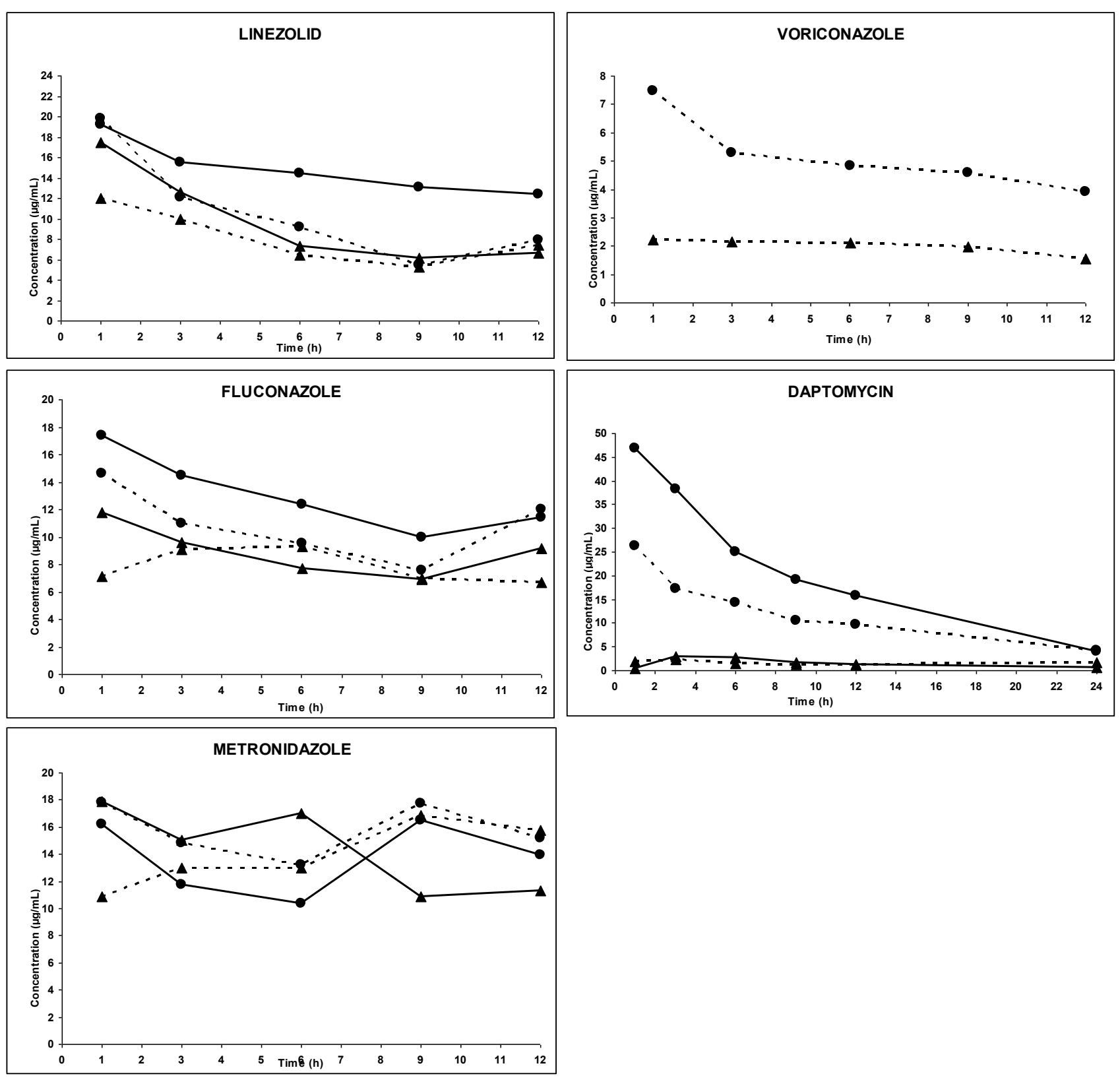

Figure 1: Evolution of arterial plasma concentrations and effluent versus time for anti-infective agents in IVOIRE study during high volume CVVH (HD) and standard volume CVVH (BD)

half-life of piperacillin was $4.3 \pm 1.2 \mathrm{~h}$, and that of tazobactam $5.6 \pm 1.3 \mathrm{~h}$. The contribution of CVVHD to the overall elimination was relevant $(>25 \%)$ for both drugs. ${ }^{[25]}$ A recent study in critically ill patients on CVVHDF receiving piperacillin-tazobactam $(4 \mathrm{~g} / 0.5 \mathrm{~g})$ every $8 \mathrm{~h}$ showed a total clearance of $5.1(4.2-6.2) \mathrm{L} / \mathrm{h}$ and 3.8 (3.3-4.2) $\mathrm{L} / \mathrm{h}$ and a CVVHDF clearance of 2.5 (2.3-3.1) $\mathrm{L} / \mathrm{h}$ and $2.5(2.3-3.2) \mathrm{L} / \mathrm{h}$ for piperacillin and tazobactam, respectively. ${ }^{[26]}$ In patients treated with CVVHDF and receiving a $4 \mathrm{~h}$ infusion of piperacillin $4 \mathrm{~g} /$ tazobactam $0.5 \mathrm{~g}$ every $8 \mathrm{~h}$, Awissi et al. found a median total clearance of $65.82 \mathrm{~mL} / \mathrm{min}(53.79-102.87)$, and a median renal clearance of $0.16 \mathrm{~mL} / \mathrm{min}(0.05-3.04)$. Median CRRT dose was $32.0 \mathrm{~mL} / \mathrm{kg} / \mathrm{h}(25.0-39.8) .{ }^{[27]}$ Although some studies suggest a better outcome in critically ill patients receiving prolonged infusion, the level of evidence is moderate. ${ }^{[28]}$ In our study, the in vivo concentration obtained after a daily high dose (16 g) continuous but not bolus infusion of piperacillin was adequate, stable throughout time, and within the recommended range for efficacy even in HVCVVH treated patients. This underscores that piperacillin treatment during CRRT is most efficacious when administered as a loading dose followed by continuous infusion especially at MIC values of 16 to $32 \mathrm{mg} / \mathrm{L} \cdot{ }^{[29]}$ 


\section{Imipenem}

Fish et al. studied the PK of imipenem during CVVH and continuous veno-venous hemodiafiltration (CVVHDF). Mean CLs and elimination half-life (t1/2) of imipenem were $145 \pm 18 \mathrm{~mL} / \mathrm{min}$ and $2.7 \pm 1.3 \mathrm{~h}$ during CVVH and $178 \pm 18 \mathrm{~mL} / \mathrm{min}$ and $2.6 \pm 1.6 \mathrm{~h}$ during CVVHDF, respectively. Imipenem clearance was substantially increased during both CVVH and CVVHDF, with membrane clearance representing respectively $25 \%$ and $32 \%$ of CLs. ${ }^{[30]}$ We found mean imipenem SC, $\mathrm{CL}_{\mathrm{CVVH}}$ and t1/2 ranging from 52.40 to $80.70 \%, 16.67$ to $65.25 \mathrm{~mL} /$ $\mathrm{min}$, and 1.29 to $1.51 \mathrm{~h}$ respectively. Total clearances were higher than previously published (158.82 to $506.83 \mathrm{~mL} /$ $\mathrm{min}$ ) with membrane clearance ranging from $9 \%$ to $18 \%$. ${ }^{[31]}$

\section{Ertapenem and doripenem}

The newer carbapenems ertapenem and doripenem are more stable after reconstitution and have a longer $\mathrm{t} 1 / 2$. Mistry et al. showed that hemodialysis cleared approximately $30 \%$ of the ertapenem dose. ${ }^{[32]}$ Hidaka et al. showed that total body clearance of doripenem was $58.0 \pm 12.7 \mathrm{~mL} /$ min, including $13.5 \pm 1.6 \mathrm{~mL} / \mathrm{min}$ CVVHDF clearance. Mean $\mathrm{t} 1 / 2$ of doripenem was $7.9 \pm 3.7 \mathrm{~h}$. Thus, under the conditions tested, CVVHDF appeared to have little effect on doripenem clearance. Therefore, serum levels of doripenem during CVVHDF can be controlled by adjustment of dose and dosing interval in accordance with residual renal function. ${ }^{[33]}$ Cirillo et al. showed that both $\mathrm{CVVH}$ and CVVHD efficiently removed doripenem with an SC of respectively $67 \%$ and $76 \%{ }^{[34]}$ We demonstrated that, despite acceptable in vivo concentrations of ertapenem or doripenem after bolus or continuous infusion, a prolonged $(4 \mathrm{~h})$ bolus or continuous infusion may be beneficial to keep concentrations longer above MIC. From our study, it can be concluded that imipenem should be replaced by doripenem or meropenem during CRRT. A higher meropenem dose (i.e., 3000 to $6000 \mathrm{mg}$ ), may be most adequate whilst preventing resistance of pathogens with MICs between 4 and $8 \mu \mathrm{g} / \mathrm{mL}$, in particular, Pseudomonas aeruginosa strains. Continuous infusion of meropenem preferred mode because the drug is stable for $8 \mathrm{~h} \cdot{ }^{[35]}$

\section{Linezolid}

Meyer et al. showed that linezolid PK during CVVH was comparable to that of healthy subjects and patients without renal impairment. The $t 1 / 2$, total clearance and hemofiltration

\begin{tabular}{|c|c|c|c|c|c|c|c|c|c|}
\hline Parameters (mean) & $n$ & $\begin{array}{l}\text { Dose } \\
\text { (mg) }\end{array}$ & $\begin{array}{c}\tau \\
\text { (h) }\end{array}$ & $\begin{array}{c}\text { Cmax } \\
(\mu \mathrm{g} / \mathrm{mL})\end{array}$ & $\begin{array}{c}\text { Cmin } \\
(\mu \mathrm{g} / \mathrm{mL})\end{array}$ & $\begin{array}{c}\text { Css } \\
(\mu \mathrm{g} / \mathrm{mL})\end{array}$ & $\begin{array}{c}\text { AUC0- } \tau \\
(\mu \mathrm{g} \cdot \mathrm{h} / \mathrm{mL})\end{array}$ & $\begin{array}{l}\text { Vd } \\
\text { (L) }\end{array}$ & $\begin{array}{c}\mathrm{T} 1 / 2 \\
\text { elimination } \\
\text { (h) }\end{array}$ \\
\hline Ertapenem HD & 5 & 1000 & 24 & 17.28 & 5.75 & - & 181.90 & 35 & 4.41 \\
\hline Ertapenem BD & 2 & 1000 & 24 & 32.39 & 17.86 & - & 327.23 & 30 & 6.79 \\
\hline Imipenem HD Intermittent infusion & 4 & 500 & 6 & 13.00 & 2.10 & - & 144.88 & 25.60 & 1.29 \\
\hline Imipenem BD Intermittent infusion & 4 & 500 & 6 & 15.30 & 3.35 & - & 209.88 & 20.70 & 1.51 \\
\hline Imipenem HD Continuous infusion & 2 & 2000 & 24 & $1.43\left(D^{*}\right)$ & $0.78\left(D^{*}\right)$ & 2.74 & - & - & - \\
\hline Imipenem BD Continuous infusion & 5 & 2000 & 24 & $4.96\left(D^{*}\right)$ & $2.33\left(D^{*}\right)$ & 7.19 & - & - & - \\
\hline Doripenem HD & 3 & 500 & 8 & 10.16 & 4.29 & - & 65.56 & 33.67 & 2.59 \\
\hline Doripenem BD & 7 & 500 & 8 & 12.82 & 5.62 & - & 80.98 & 52.61 & 4.21 \\
\hline Ceftriaxone HD & 2 & 2000 & 24 & 225.62 & 5.16 & - & 235.32 & 51.32 & 4.19 \\
\hline Ceftriaxone BD & 4 & 2000 & 24 & 283.65 & 6.85 & - & 415.37 & 40.13 & 5.76 \\
\hline Piperacillin HD Intermittent infusion & 5 & 4000 & 6 & 145.62 & 35.56 & - & 122.52 & 38.29 & 3.61 \\
\hline Piperacillin BD Intermittent infusion & 2 & 4000 & 6 & 78.35 & 39.82 & - & 147.63 & 50.99 & 3.99 \\
\hline Piperacillin HD Continuous infusion & 10 & 16000 & 24 & $91.62\left(D^{*}\right)$ & $66.38\left(D^{*}\right)$ & 158.71 & 90.47 & - & - \\
\hline Piperacillin BD Continuous infusion & 9 & 16000 & 24 & $\begin{array}{c}147.04 \\
\left(D^{*}\right)\end{array}$ & $\begin{array}{c}109.76 \\
\left(D^{*}\right)\end{array}$ & 256.54 & 42.74 & - & - \\
\hline Ofloxacin HD & 14 & 200 & 12 & 8.47 & 3.38 & - & 64.73 & 32.54 & 6.58 \\
\hline Ofloxacin BD & 8 & 200 & 12 & 8.77 & 2.44 & - & 52.02 & 51.46 & 8.72 \\
\hline Linezolid HD & 2 & 600 & 12 & 17.55 & 6.68 & - & 129.63 & 46.76 & 6.33 \\
\hline Linezolid BD & 3 & 600 & 12 & 21.50 & 4.30 & - & 131.31 & 30.70 & 4.59 \\
\hline Daptomycin HD & 4 & $6 \mathrm{mg} / \mathrm{kg}$ & 24 & 55.22 & 7.53 & - & 477.72 & 20.26 & 8.53 \\
\hline Daptomycin BD & 7 & $6 \mathrm{mg} / \mathrm{kg}$ & 24 & 54.93 & 10.91 & - & 510.99 & 17.70 & 11.94 \\
\hline Metronidazole HD & 12 & 500 & 8 & 15.97 & 10.61 & - & 262.57 & 42 & 8.22 \\
\hline Metronidazole BD & 12 & 500 & 8 & 18.63 & 10.72 & - & 236.17 & 54 & 10.18 \\
\hline Fluconazole HD & 2 & 400 & 12 & 17.40 & 9.10 & - & 114.39 & 73.38 & 28.54 \\
\hline Fluconazole BD & 1 & 400 & 12 & 14.60 & 7.60 & - & 96.44 & 103.71 & 33.85 \\
\hline Voriconazole BD & 3 & $3 \mathrm{mg} / \mathrm{kg}$ & 12 & 7.37 & 4.79 & - & 55.00 & 65.55 & 7.19 \\
\hline
\end{tabular}

$\mathrm{V}_{\mathrm{d}}=\mathrm{CL}_{\mathrm{s}} / \mathrm{K}_{\mathrm{el}} ; \mathrm{K}_{\mathrm{el}}=\mathrm{Ln} 2 / \mathrm{T}_{1 / 2 \mathrm{Kel}} ; \mathrm{T}_{1 / 2 \mathrm{Kel}}=$ elimination half-life; $\mathrm{D}^{*}=$ loading dose; $\mathrm{V}_{\mathrm{d}}=$ volume of distribution; $\mathrm{T}_{1 / 2}=$ elimination half-life; $\tau=$ time interval between two administrations; $\mathrm{C}_{\max }=$ maximum arterial concentration at the end of infusion; $\mathrm{C}_{\min }=$ trough arterial concentration; $\mathrm{C}_{\mathrm{ss}}=$ the steady-state arterial concentration for continuous infusion; $\mathrm{AUC}_{0-\tau}=$ area under the curve for plasma concentrations between 0 and $\tau ; n=$ number of patients. 
clearance were $4.3 \pm 1.7 \mathrm{~h}, 9.3 \pm 3.5 \mathrm{~L} / \mathrm{h}$ and $1.9 \pm 0.8 \mathrm{~L} / \mathrm{h}$, respectively. ${ }^{[3]]}$ Pea et al. identified significant elimination of linezolid in patients undergoing CVVH. Total clearance was $25 \%$ higher and serum trough concentration $50 \%$ lower. In $93 \%$ of the patients, serum concentrations above MIC were obtained after the administration of a standard dose $(600 \mathrm{mg}$ every $12 \mathrm{~h}$ ) of linezolid. However, the mean T\% MIC was only $57 \%$ of the dosing interval for pathogens with a MIC of $4 \mathrm{mg} / \mathrm{L}$. Thus, $600 \mathrm{mg}$ of linezolid every $8 \mathrm{~h}$ may be necessary to assure optimal antibacterial activity. ${ }^{[37]}$

We suggest that, whenever possible, time-dependent antibiotics should be administered in continuous infusion during CRRT. As the risk of overdosing is limited and to avoid underdosing, higher than currently recommended doses should be prescribed, particularly when the range of therapeutic concentrations is large. ${ }^{[19]}$

Drugs moderately influenced by CRRT (or when CVVH clearance largely contributes to total body clearance in AKI)

In this category, antibiotic clearance is close to normal clearance in patients without AKI. Standard doses may be sufficient for optimal treatment.

\section{Concentration-dependent killing Metronidazole}

In patients undergoing dialysis, plasma $t 1 / 2$ of metronidazole was $6.8 \mathrm{~h}$, which is comparable with healthy subjects. Dialysis clearance of metronidazole was $60 \mathrm{~mL} / \mathrm{min}$ with $25 \%$ drug eliminated at the start of treatment. ${ }^{[38]}$ Kreeft et al. found that plasma metronidazole concentrations in patients with renal insufficiency were similar to those in patients with normal renal function. Moreover, renal insufficiency did not affect beta half-life $(6.5 \mathrm{~h})$ or plasma clearance $(10.1 \mathrm{~L} / \mathrm{h})$ of metronidazole. ${ }^{[39]}$ In our study, mean metronidazole $\mathrm{SC}, \mathrm{CL}_{\mathrm{CVVH}}$ and $\mathrm{t} 1 / 2$ ranged from 82.10 to $89.30 \%, 26.43$ to $58.91 \mathrm{~mL} / \mathrm{min}$, and 8.22 to $10.18 \mathrm{~h}$ respectively. Accordingly, a dose of 1500 $\mathrm{mg}$ once daily is proposed. The currently prescribed dose of $500 \mathrm{mg}$ three times daily should be abandoned!

\section{Ofloxacin}

During CVVH, Fuhrmann et al. found a mean serum ofloxacin concentration peak of $5.5 \pm 0.7 \mathrm{mg} / \mathrm{L}$ and a $\mathrm{t} 1 / 2$, hemofiltration clearance, and total removal of $2.8 \pm 0.5 \mathrm{~h}$, $89.9 \pm 4.5 \mathrm{~mL} / \mathrm{min}$, and $76.9 \% \pm 7.1 \%$, respectively. ${ }^{[40]} \mathrm{In}$ our study, mean ofloxacin $\mathrm{SC}, \mathrm{CL}_{\mathrm{CVVH}}$ and $\mathrm{t} 1 / 2$ ranged from 59.50 to $66.00 \% ; 18.74$ to $52.19 \mathrm{~mL} / \mathrm{min}$ and 6.58 to

\begin{tabular}{|c|c|c|c|c|c|c|c|}
\hline Paramètres (moyenne) & $\begin{array}{c}\text { CLs } \\
(\mathrm{mL} / \mathrm{min})\end{array}$ & $\begin{array}{c}\text { Cs } \\
(\%)\end{array}$ & $\begin{array}{c}\text { QUF } \\
(\mathrm{mL} / \mathrm{min})\end{array}$ & $\begin{array}{c}\text { Dilution } \\
\text { factor }(\%)\end{array}$ & $\begin{array}{l}\text { CLCVVH } \\
\text { (mL/min) }\end{array}$ & $\begin{array}{c}\text { CLCVVH/ } \\
\text { CLs } \\
(\%)\end{array}$ & $\begin{array}{c}\text { CLNR } \\
\text { (mL/min) }\end{array}$ \\
\hline Ertapenem HD & 91.63 & 55.90 & 95.83 & 77 & 41.50 & 45 & 50.13 \\
\hline Ertapenem BD & 50.93 & 38.70 & 42.67 & 84 & 13.93 & 27 & 37 \\
\hline Imipenem HD Intermittent infusion & 230.08 & 66.90 & 75.83 & 80 & 40.58 & 18 & 189.50 \\
\hline Imipenem BD Intermittent infusion & 158.82 & 71.60 & 32.50 & 86 & 20.01 & 13 & 138.80 \\
\hline Imipenem HD Continuous infusion & 506.83 & 80.70 & 105.00 & 77 & 65.25 & 13 & 441.58 \\
\hline Imipenem BD Continuous infusion & 193.16 & 52.40 & 37.00 & 86 & 16.67 & 9 & 176.49 \\
\hline Doripenem HD & 150.38 & 90.1 & 102.00 & 84 & 77.20 & 51 & 73.18 \\
\hline Doripenem BD & 144.33 & 75.60 & 32.00 & 80 & 19.35 & 13 & 124.98 \\
\hline Ceftriaxone HD & 141.65 & 49.60 & 86.58 & 88 & 37.79 & 27 & 103.86 \\
\hline Ceftriaxone BD & 80.25 & 64.60 & 35.24 & 79 & 17.98 & 22 & 62.27 \\
\hline Pipéracillin HD Intermittent infusion & 122.52 & 96.70 & 103.05 & 88 & 87.69 & 72 & 34.83 \\
\hline Pipéracillin BD Intermittent infusion & 147.63 & 92.56 & 35.50 & 82 & 29.94 & 18 & 117.69 \\
\hline Pipéracillin HD Continuous infusion & 90.48 & 70.50 & 98.50 & 86 & 59.72 & 66 & 30.76 \\
\hline Pipéracillin BD Continuous infusion & 42.74 & 80.10 & 30.00 & 80 & 19.22 & 45 & 23.52 \\
\hline Ofloxacin HD & 56.93 & 59.50 & 102.00 & 86 & 52.19 & 92 & 49.44 \\
\hline Ofloxacin BD & 68.18 & 66.00 & 35.50 & 80 & 18.74 & 28 & 4.74 \\
\hline Linezolid HD & 84.94 & 76.20 & 102.00 & 77 & 59.84 & 70.50 & 55.48 \\
\hline Linezolid BD & 77.26 & 80.50 & 33.00 & 82 & 21.78 & 28 & 25.10 \\
\hline Daptomycin HD & 27.42 & 12.50 & 105.00 & 88 & 11.55 & 42 & 15.87 \\
\hline Daptomycin BD & 17.11 & 15.80 & 37.00 & 85 & 4.97 & 29 & 12.14 \\
\hline Metronidazole HD & 59.09 & 82.10 & 92.00 & 78 & 58.91 & 100 & 19.78 \\
\hline Metronidazole BD & 61.22 & 89.30 & 37.00 & 80 & 26.43 & 43 & 0.18 \\
\hline Fluconazole HD & 29.35 & 59.20 & 85.00 & 80 & 26.05 & 89 & 14.79 \\
\hline Fluconazole BD & 34.57 & 75.40 & 32.00 & 82 & 19.78 & 57 & 0.30 \\
\hline Voriconazole BD & 105.31 & 40.50 & 35.00 & 88 & 12.47 & 12 & 92.84 \\
\hline
\end{tabular}


Breilh et al.: Pharmacokinetics and pharmacodynamics of anti-infective agents

\begin{tabular}{|c|c|c|c|c|}
\hline Antibiotic & Isolated Pathogen & $M I C(\mu g / m L)$ & T\% $>$ MIC & $\mathrm{IQ}=\mathrm{Cmax} / \mathrm{CMI}$ or Css $/ \mathrm{CMI}$ \\
\hline \multirow[t]{7}{*}{ Imipenem } & Pseudomonas aeruginosa (1) & 3 & 34 & 4 \\
\hline & Escherichia coli $(1)$ & 1 & 57 & 11 \\
\hline & Enterococcus faecalis (1) & 3 & 37 & 4 \\
\hline & Streptococcus sp. (1) & 2 & 57 & 9 \\
\hline & Klebsiella pneumoniae (1) & 0.5 & 85 & 23 \\
\hline & Pseudomonas aeruginosa (2) & 1 & 43 & 13 \\
\hline & Enterobacter cloacae (1) & 2 & 65 & 6 \\
\hline \multirow[t]{7}{*}{ Ofloxacin } & Klebsiella oxytoca (1) & 0.3 & - & 17 \\
\hline & Moraxella catarrhalis (1) & 0,25 & - & 22 \\
\hline & Enterobacter cloacae(2) & 0,25 & - & 46 \\
\hline & Moraxella catarrhalis (2) & 0.3 & - & 36 \\
\hline & Pseudomonas aeruginosa (3) & 2 & - & 5 \\
\hline & Escherichia coli $(3)$ & 1 & - & 6 \\
\hline & Serratia $s p$ & 1 & - & 6 \\
\hline \multirow[t]{14}{*}{ Piperacillin } & Enterobacter cloacae (3) & 3 & 100 & 11 \\
\hline & Stenotrophomonas maltophila & 12.5 & 84 & 10 \\
\hline & Streptococcus sp. (2) & 0,05 & 100 & 700 \\
\hline & Escherichia coli (4) & 1 & 100 & 49 \\
\hline & Acinetobacter baumanii (1) & 9 & 100 & 4 \\
\hline & Enterobacter cloacae (4) & 3 & 100 & 11 \\
\hline & Klebsiella oxytoca (2) & 14 & 100 & 9 \\
\hline & Pseudomonas aeruginosa (4) & 2 & 100 & 20 \\
\hline & Escherichia coli $(5)$ & 26 & 58 & 5 \\
\hline & Proteus mirabilis & 0,06 & 100 & 583 \\
\hline & Acinetobacter baumanii (2) & 4 & 80 & 9 \\
\hline & Escherichia coli $(6)$ & 0.2 & 100 & 159 \\
\hline & Streptococcus haemolysis & 0,05 & 65 & 10 \\
\hline & Enterobacter aerogenes (1) & 1 & 100 & 49 \\
\hline \multirow[t]{4}{*}{ Ceftriaxone } & Escherichia coli (7) & 0,02 & 100 & 10000 \\
\hline & Enterococcus faecalis (4) & 6 & 48 & 35 \\
\hline & Escherichia coli (8) & 0,02 & 83 & 10000 \\
\hline & Enterococcus faecalis (5) & 0.3 & 58 & 588 \\
\hline \multirow[t]{7}{*}{ Ertapenem } & Klebsiella oxytoca (3) & 0,2 & 100 & 50 \\
\hline & Enterobacter cloacae (5) & 0,1 & 100 & 100 \\
\hline & Escherichia coli (9) & 0.5 & 80 & 200 \\
\hline & Enterobacter cloacae (6) & 1 & 90 & 100 \\
\hline & Klebsiella oxytoca (4) & 0.5 & 90 & 200 \\
\hline & Enterobacter cloacae (7) & 1 & 78 & 100 \\
\hline & Klebsiella oxytoca (5) & 0,06 & 100 & 1667 \\
\hline \multirow[t]{3}{*}{ Linezolid } & Staphylococcus aureus (1) & 2.50 & 32 & 8 \\
\hline & Staphylococcus aureus (2) & 1 & 90 & 20 \\
\hline & Staphylococcus aureus (3) & 0.5 & 80 & 40 \\
\hline \multirow[t]{7}{*}{ Doripenem } & Enterobacter cloacae (8) & 1 & & 12 \\
\hline & Enterobacter aerogenes (2) & 0,03 & 100 & 375 \\
\hline & Acinetobacter baumanii (3) & 2 & 88 & 6 \\
\hline & Pseudomonas aeruginosa (5) & 1 & 100 & 12 \\
\hline & Pseudomonas aeruginosa (6) & 2 & 100 & 6 \\
\hline & Pseudomonas aeruginosa (7) & 1 & 100 & 12 \\
\hline & Enterococcus faecalis (6) & 1.5 & 80 & 9 \\
\hline \multirow[t]{4}{*}{ Daptomycin } & Staphylococcus aureus (4) & 0.5 & 100 & 110 \\
\hline & Staphylococcus aureus (5) & 1 & 90 & 55 \\
\hline & Enterococcus faecalis (2) & 1 & 88 & 55 \\
\hline & Enterococcus faecalis (3) & 1 & 70 & 55 \\
\hline \multirow[t]{2}{*}{ Metronidazole } & Bacterioides fragilis (1) & 0.5 & 90 & 20 \\
\hline & Bacterioides fragilis (2) & 0.5 & 90 & 20 \\
\hline
\end{tabular}


Breilh et al.: Pharmacokinetics and pharmacodynamics of anti-infective agents

\begin{tabular}{|c|c|c|}
\hline Antimicrobial & Loading dose & Maintenance dose \\
\hline Amikacin & $30-35 \mathrm{mg} / \mathrm{kg}$ & TDM \\
\hline Meropenem & $2 \mathrm{~g}$ & $2 \mathrm{~g}$ over $3 \mathrm{~h}$ tid \\
\hline Piperacillin-tazobactam & $4 \mathrm{~g} / 0.5 \mathrm{~g}$ & $16 \mathrm{~g} / 2 \mathrm{~g}(\mathrm{Cl})$ \\
\hline Vancomycin & $35 \mathrm{mg} / \mathrm{kg}$ over $4 \mathrm{~h}$ & $30 \mathrm{mg} / \mathrm{kg}(\mathrm{TDM}=25-30 \mathrm{mg} / \mathrm{L})$ \\
\hline Teicoplanin & $15 \mathrm{mg} / \mathrm{kg}$ bid & $600 \mathrm{mg}$ od \\
\hline Linezolid & & $600 \mathrm{mg}$ tid \\
\hline Ciprofloxacin & $800 \mathrm{mg}$ & $400 \mathrm{mg}$ tid \\
\hline Tigecyclin & $150 \mathrm{mg}$ & $100 \mathrm{mg}$ bid \\
\hline Colistin & $9 \mathrm{MIU}$ & 4.5 MIU tid \\
\hline Voriconazole & $8 \mathrm{mg} / \mathrm{kg}$ bid & $6 \mathrm{mg} / \mathrm{kg}$ bid \\
\hline Fluconazole & & $600 \mathrm{mg}$ bid \\
\hline Cefepime & & $2 \mathrm{~g}$ tid \\
\hline Gentamycin & & $7 \mathrm{mg} / \mathrm{kg}$ od \\
\hline Bactrim & 1200 mg/240 mg (3 amp) & $800 \mathrm{mg} / 160 \mathrm{mg}(2 \mathrm{amp})$ tid \\
\hline Clindamycin & & $900 \mathrm{mg}$ qid \\
\hline
\end{tabular}

$\mathrm{TDM}=$ therapeutic drug monitoring; od = once daily; bid = twice daily; tid = three times daily; qid = four times daily; amp = ampules; $\mathrm{Cl}=\mathrm{continuous}$ infusion; MIU = million units. According to references No. 68-77 - Adapted and changed from reference No. 63.

$8.72 \mathrm{~h}$, respectively. However, due to the high volume of distribution, serum concentration is comparable between the standard and high volume group, implying that no dose adaptation is required at increasing CVVH dose. Choi et al. ${ }^{[41]}$ studied levofloxacin in an in vitro CVVH model and found significantly less drug adsorption on a polyamide than on a polyacrylonitrile (PAN) filter. Polyethersulfone used in our study has a pretty bad record regarding almost no drug adsorption. ${ }^{[42]}$ Post-dilution resulted in a small but statistically significant decrease in SC when a PAN filter was used.

\section{Time-dependent killing \\ Fluconazole}

Fluconazole has a low protein binding and a low molecular weight. About $80 \%$ is eliminated unchanged by the kidneys. Fluconazole is effectively cleared by hemodialysis and hemofiltration. ${ }^{[43-44]}$ Pittrow and Penk showed that patients undergoing CRRT require a similar loading dose of fluconazole as patients with normal renal function. Thereafter, a maintenance dose is given adjusted for anuria by multiplying with a factor accounting for extracorporeal elimination of the absorbed dose. ${ }^{[4]}$ Yagasaki et al. found that continuous hemodiafiltration is highly effective for fluconazole removal. Fluconazole should be administered at a dose of 500 to $600 \mathrm{mg}$ every $12 \mathrm{~h}{ }^{[46]}$ but close hepatic, neurological, and ECG (QT interval!) monitoring is mandatory. Bergner et al. measured plasma fluconazole concentrations during CVVHDF. ${ }^{[4]}$ All patients reached levels between 16 and $32 \mathrm{mg} / \mathrm{L}$, which remained in this range for minimal 1 and up to $24 \mathrm{~h}$ (on average $9.6 \mathrm{~h}$ at an UF rate of $2000 \mathrm{~mL} / \mathrm{h}$ and $15.7 \mathrm{~h}$ at an UF rate of $1000 \mathrm{~mL} / \mathrm{h}$ ). Thus, a once-daily dose of $800 \mathrm{mg}$ fluconazole is necessary to achieve optimal fungicidal activity. ${ }^{[4]} \mathrm{CVVH}$ effectively removes fluconazole from the circulation by a clearance into the hemofiltrate of approximately
$21 \mathrm{~mL} / \mathrm{min}$. This implies no dose reduction during CVVH. ${ }^{[48]}$ Muhl et al. compared the elimination of fluconazole during continuous veno-venous hemodialysis (CVVHD) and CVVH at different dosages. Extracorporeal clearance (CVVHD $30.5 \mathrm{~mL} / \mathrm{min}$, CVVH $17.5 \mathrm{~mL} / \mathrm{min}$ ) and total clearance of fluconazole (CVVHD $37.9 \mathrm{~mL} /$ min, CVVH $25.3 \mathrm{~mL} / \mathrm{min}$ ) were significantly higher during CVVHD. During CVVHD, the sieving coefficient (S) (CVVHD) was 0.88 and t $1 / 2$ was $14.8-35.1 \mathrm{~h}$. During $\mathrm{CVVH}$, the $\mathrm{S}(\mathrm{CVVH})$ was 0.96 and $\mathrm{t} 1 / 2$ was $24.0-51.6 \mathrm{~h}$. Since CVVHD clearance may considerably exceed the clearance in patients with normal renal function, a daily dose of 400 to $800 \mathrm{mg}$ is recommended during CVVHD $\cdot{ }^{[4]}$ In our study, mean fluconazole SC, $\mathrm{CL}_{\mathrm{CVVH}}$ and t1/2 ranged from 59.20 to $75.40 \%, 19.78$ to $26.05 \mathrm{~mL} /$ $\mathrm{min}$, and 28.54 to $33.85 \mathrm{~h}$, respectively. Taken together, fluconazole should be administered at a dose of 500 to $600 \mathrm{mg}$ every $12 \mathrm{~h}{ }^{[46]}$ Point of care dosing of fluconazole could be an interesting option. ${ }^{[50]}$

\section{Drugs not influenced by CRRT Time dependent killing Ceftriaxone}

Ceftriaxone clearance in patients receiving CVVHD is equivalent to clearance in subjects with normal renal function. Therefore, no dose adjustment is necessary. ${ }^{[1,52]}$ In hemodialyzed patients, administration of $2 \mathrm{~g}$ ceftriaxone resulted in a T > MIC of 88.5 (78.8-98.3) $\mathrm{h}$ and 17.7 (13.322.0) $\mathrm{h}$ for MIC breakpoints of $1 \mathrm{and} 8 \mathrm{mg} / \mathrm{L}$, respectively. ${ }^{[53]}$ See comment in PubMed Commons belowIn patients with various degrees of renal impairment, Patel et al. confirmed the PK efficacy of a $2 \mathrm{~g}$ ceftriaxone dose. T1/2 (group mean ranged from 11.7 to $17.3 \mathrm{~h}$ ) and plasma clearance (group mean ranged from 529 to $705 \mathrm{ml} / \mathrm{h}$ ) showed no correlation with creatinine clearance. ${ }^{[54]}$ In our study, 
mean ceftriaxone $\mathrm{SC}, \mathrm{CL}_{\mathrm{CVvH}}$ and $\mathrm{t} 1 / 2$ ranged from 49.60 to $64.60 \%, 17.98$ to $37.79 \mathrm{~mL} / \mathrm{min}$ and 4.19 to $5.76 \mathrm{~h}$, respectively.

\section{Concentration dependent killing Daptomycin}

Salama et al. obtained sufficient pre-hemodialysis serum concentrations after thrice-weekly post-hemodialysis administration of $6 \mathrm{mg} / \mathrm{kg}$ daptomycin even after a 68 $\mathrm{h}$ interval between dialysis sessions. ${ }^{[5]}$ Mean urea and daptomycin reduction ratios were $79.6 \pm 5.8 \%$ and $57.6 \pm$ $9.2 \%$, respectively. Daptomycin half-life was $19.4 \pm 6.5$ and $3.8 \pm 1.1 \mathrm{~h}$ "off" and "on" hemodialysis, respectively, with minimal rebound $1 \mathrm{~h}$ post-hemodialysis. Churchwell et al. studied transmembrane clearance of daptomycin during CVVH and CVVHD in an in vitro model that employed AN69 and polysulfone hemodiafilters at varying ultrafiltrate and dialysate flow rates. Clearance depended on filter type and dialysate and ultrafiltration rates. High ultrafiltrate or dialysate rates resulted in substantial daptomycin clearance.${ }^{[5]}$ Corti et al. found no significant accumulation of daptomycin when a dose of $6 \mathrm{mg} / \mathrm{kg}$ was given to patients undergoing CRRT with an effluent flow rate $>30 \mathrm{~mL} / \mathrm{kg} / \mathrm{h}{ }^{[57]}$ In our study, mean daptomycin SC, $\mathrm{CL}_{\mathrm{CVVH}}$ and $\mathrm{t} 1 / 2$ ranged from 12.50 to $15.80 \%, 4.97$ to $11.55 \mathrm{~mL} / \mathrm{min}$ and 8.53 to $11.94 \mathrm{~h}$, respectively.

\section{Voriconazole}

Being poorly water-soluble, the intravenous voriconazole formulation includes the vehicle sulfobutylether-betacyclodextrin sodium (SBECD). SBECD is not proteinbound and predominantly eliminated by glomerular filtration. Intravenous voriconazole is not recommended in patients with a creatinine clearance $<50 \mathrm{~mL} / \mathrm{min}$ because of potentially toxic accumulation of SBECD.$^{[58]}$ Tyree et al. recently showed that CVVH effectively removed SBECD at a rate similar to the ultrafiltration rate. ${ }^{[59]}$ Voriconazole clearance by CVVH was not clinically significant. Standard doses of intravenous voriconazole can be used safely in patients undergoing CVVH. Quintard et al. studied voriconazole PK during HV-CVVH. See comment in PubMed Commons belowThe total body clearance of voriconazole was $5.4 \mathrm{~L} / \mathrm{h}$ with a half-life of $16.5 \mathrm{~h}$ and a distribution volume of $128.6 \mathrm{~L}$. The estimated SC was 0.58 and the filtration clearance $1.39 \mathrm{~L} / \mathrm{h}$. HV-CVVH may affect voriconazole disposition more than other techniques. ${ }^{[60,61]}$ When voriconazole doses mount to 6 $\mathrm{mg} / \mathrm{kg}$ per $12 \mathrm{~h}$, intermittent hemodialysis may fail to completely eliminate SBECD. CRRT is then recommended to avoid vehicle-induced toxicity. ${ }^{[61,62]}$

\section{STUDY LIMITATIONS}

The current study has major flaws and limitations. First, therapeutic drug monitoring remained observational and was not applied to improve PK/PD of the studied antimicrobials. Evaluating the impact of many relevant patient- and technique-related variables influencing PK/ PD (i.e., distribution volume, membrane type, MIC of the micro-organisms, quality of resuscitation $)^{[63-65]}$ also remained beyond the scope of the study. Second, at the time of study, all patients received unfractionated heparin for extracorporeal circuit anticoagulation. Today, regional citrate anticoagulation is increasingly used. Citrate better preserves porosity and adsorptive capacity of the membrane, which inherently results in different antimicrobial elimination. ${ }^{[6,66]}$ Third, non-adsorptive membranes were used, which have been progressively supplanted by highly adsorptive membranes. The latter more effectively eliminate antimicrobials through bulk rather than surface adsorption. ${ }^{[64,67,68]}$ Finally, data were gathered during HV-CVVH, which did not prove to be superior to SV-CVVH. ${ }^{[1]}$

\section{CONCLUSIONS \& PERSPECTIVES}

As expected, HV-CVVH eliminated more antibiotics than SV-CVVH. All agents were easily filtered. Mean elimination $\mathrm{t} 1 / 2$ of all agents was significantly shorter during HV$\mathrm{CVVH}$ than during SV-CVVH. CLs, $\mathrm{CL}_{\mathrm{CVVH}}$, and $\mathrm{CL}_{\mathrm{NR}}$ of all agents were significantly higher during HV-CVVH.

Antibiotics that are highly removed by CRRT should be preferentially administered as a continuous infusion. A loading dose of $4 \mathrm{~g}$ followed by a continuous infusion of $16 \mathrm{~g}$ provides the most optimal PK for piperacillin. Regarding carbapenems, our results argue against the use of imipenem during CRRT. Doripenem or meropenem are better options. A meropenem dose of 3 to $6 \mathrm{~g}$ is required to adequately treat pathogens with MICs between 4 to $8 \mathrm{mg} / \mathrm{L}$, especially Pseudomonas aeruginosa strains. As meropenem was found to be stable for $8 \mathrm{~h}$, it can be given as a continuous perfusion. In almost all patients, linezolid concentrations above the MIC were obtained after administration of a standard dose (600 mg every $12 \mathrm{~h}$ ) but optimal antibacterial activity at a MIC of $4 \mathrm{mg} / \mathrm{L}$ requires $600 \mathrm{mg}$ linezolid every $8 \mathrm{~h}$.

During CRRT, the "classical" $500 \mathrm{mg}$ three times daily metronidazole dose should be abandoned and replaced by a $1500 \mathrm{mg}$ once daily dose. The dose of fluconazole must be increased to 500 to $600 \mathrm{mg}$ every $12 \mathrm{~h}$. When higher doses of voriconazole (up to $6 \mathrm{mg} / \mathrm{kg}$ per $12 \mathrm{~h}$ ) are needed, intermittent hemodialysis should be replaced by CRRT to avoid toxicity induced by the SBECD vehicle.

CRRT significantly influences the PK/PD behavior of most antimicrobial agents. This is insufficiently anticipated by the current dosing guidelines. Patients are particularly at 
risk for underdosing, which may cause treatment failure and enhance resistance. Table 5 depicts dose recommendations for some major antibiotic and antifungal drugs during CVVH (at a dose of $25 \mathrm{~mL} / \mathrm{kg} / \mathrm{h}$ ) that are based upon relevant literature data ${ }^{[69-77]}$ and our own findings.

\section{Conflict of Interest}

The authors declare to have no competing interests.

\section{REFERENCES}

1. Roberts JA, Lipman J. Pharmacokinetic issues for antibiotics in the critically ill patient. Crit Care Med 2009;37:840-51; quiz 859.

2. Fissell WH. Antimicrobial Dosing in Acute Renal Replacement. Adv Chronic Kidney Dis 2013; 20: 85-93.

3. Bugge JF. Pharmacokinetics and drug dosing adjustments during continuous venovenous hemofiltration or hemodiafiltration in critically ill patients. Acta Anaesthesiol Scand 2001;45:929-34.

4. Trotman RL, Williamson JC, Shoemaker DM, Salzer WL. Antibiotic dosing in critically ill adult patients receiving continuous renal replacement therapy. Clin Infect Dis 2005; 41:1159-66

5. Vesconi S, Cruz DN, Fumagalli R, Kindgen-Milles D, Monti G, Marinho A, et al. Delivered dose of renal replacement therapy and mortality in critically ill patients with acute kidney injury. Crit Care 2009;13:R57.

6. Uchino S1, Bellomo R, Morimatsu H, Morgera S, Schetz M, Tan I, et al. Continuous renal replacement therapy: a worldwide practice survey. The beginning and ending supportive therapy for the kidney (B.E.S.T. kidney) investigators. Intensive Care Med 2007;33:1563-70.

7. Cornejo R1, Downey P, Castro R, Romero C, Regueira T, Vega J, et al. High-volume hemofiltration as salvage therapy in severe hyperdynamic septic shock. Intensive Care Med 2006;32:713-22.

8. Joannes-Boyau O, Rapaport S, Bazin R, Fleureau C, Janvier G. Impact of high volume hemofiltration on hemodynamic disturbance and outcome during septic shock. Asaio J 2004;50:102-9.

9. Honore PM, Jamez J, Wauthier M, Lee PA, Dugernier T, Pirenne B, et al. Prospective evaluation of short-term, high-volume isovolemic hemofiltration on the hemodynamic course and outcome in patients with intractable circulatory failure resulting from septic shock. Crit Care Med 2000;28:3581-7.

10. Bouman CS, van Kan HJ, Koopmans RP, Korevaar JC, Schultz MJ, Vroom MB. Discrepancies between observed and predicted continuous venovenous hemofiltration removal of antimicrobial agents in critically ill patients and the effects on dosing. Intensive Care Med 2006;32:2013-9.

11. Joannes-Boyau O, Honoré PM, Perez P, Bagshaw SM, Grand H, Canivet $\mathrm{JL}$, et al. High-volume versus standard-volume haemofiltration for septic shock patients with acute kidney injury (IVOIRE study): a multicentre randomized controlled trial. Intensive Care Med 2013;39:1535-46.

12. Bilgrami I, Roberts JA, Wallis SC, Thomas J, Davis J, Fowler S, et al. Meropenem Dosing in Critically Ill Patients with Sepsis Receiving HighVolume Continuous Venovenous Hemofiltration. Antimicrob Agents Chemother 2010; 54:2974-8.

13. Toutain J1, Boselli E, Djabarouti S, Allaouchiche B, Xuereb F, Bernadou JM, et al. Determination of linezolid in plasma and bronchoalveolar lavage by high-performance liquid chromatography with ultraviolet detection using a fully automated extraction method. J Chromatogr B Analyt Technol Biomed Life Sci 2004;813:145-50.

14. Gordien JB1, Pigneux A, Vigouroux S, Tabrizi R, Accoceberry I, Bernadou $\mathrm{JM}$, et al. Simultaneous determination of five systemic azoles in plasma by high-performance liquid chromatography with ultraviolet detection. J Pharm Biomed Anal 2009;50:932-8.
15. Gordien JB1, Boselli E, Fleureau C, Allaouchiche B, Janvier G, Lalaude $\mathrm{O}$, et al. Determination of free ertapenem in plasma and bronchoalveolar lavage by high-performance liquid chromatography with ultraviolet detection. J Chromatogr B Analyt Technol Biomed Life Sci 2006;830:21823.

16. FDA. Guidance for industry, Bioanalytical Method Validation. U.S. Department of Health and Human Services Food and Drug Administration 2018 (CDER, CVM). Available from URL at: https://www.fda.gov/ files/drugs/published/Bioanalytical-Method-Validation-Guidance-forIndustry.pdf. Last accessed on December 9, 2019.

17. Pea F, Viale P, Pavan F, Furlanut M. Pharmacokinetic considerations for antimicrobial therapy in patients receiving renal replacement therapy. Clin Pharmacokinet 2007;46:997-1038.

18. Ulldemolins M, Vaquer S, Llauradó-Serra M, Pontes C, Calvo G, Soy D, et al. Beta-lactam dosing in critically ill patients with septic shock and continuous renal replacement therapy. Crit Care 2014;18:227

19. Seyler L, Cotton F, Taccone FS, De Backer D, Macours P, Vincent $\mathrm{JL}$, et al. Recommended $\beta$-lactam regimens are inadequate in septic patients treated with continuous renal replacement therapy. Crit Care 2011;15:R137.

20. Taccone FS, de Backer D, Laterre PF, Spapen H, Dugernier T, Delattre I, et al. Pharmacokinetics of a loading dose of amikacin in septic patients undergoing continuous renal replacement therapy. Int J Antimicrob Agents 2011;37:531-5.

21. Choi G, Gomersall CD, Tian Q, Joynt GM, Freebairn R, Lipman J. Principles of antibacterial dosing in continuous renal replacement therapy. Crit Care Med 2009;37:2268-82.

22. Golper TA, Marx MA. Drug dosing adjustments during continuous renal replacement therapies. Kidney Int Suppl 1998; 66:S165-8.

23. Roberts JA, Lipman J. Antibacterial dosing in intensive care: pharmacokinetics, degree of disease and pharmacodynamics of sepsis. Clin Pharmacokinet 2006;45: 755-73.

24. Rodvold KA. Pharmacodynamics of antiinfective therapy: taking what we know to the patient's bedside. Pharmacotherapy 2001; 21:319S-30S.

25. Mueller SC, Majcher-Peszynska J, Hickstein H, Francke A, Pertschy A, Schulz M, et al. Pharmacokinetics of piperacillin-tazobactam in anuric intensive care patients during continuous venovenous hemodialysis. Antimicrob Agents Chemother 2002;46:1557-60.

26. Varghese JM, Jarrett P, Boots RJ, Kirkpatrick CM, Lipman J, Roberts JA. Pharmacokinetics of piperacillin and tazobactam in plasma and subcutaneous interstitial fluid in critically ill patients receiving continuous venovenous haemodiafiltration. Int J Antimicrob Agents 2014,43:343-8.

27. Awissi DK, Beauchamp A, Hébert E, Lavigne V, Munoz DL, Lebrun G, et al. Pharmacokinetics of an Extended 4-hour Infusion of PiperacillinTazobactam in Critically Ill Patients Undergoing Continuous Renal Replacement Therapy. Pharmacotherapy 2015;35:600-7.

28. Yusuf E, Spapen HD, Piérard D. Prolonged vs intermittent infusion of piperacillin/tazobactam in critically ill patients: a narrative and systematic review. J Crit Care. 2014;29:1089-95.

29. Asín-Prieto E, Rodríguez-Gascón A, Trocóniz IF, Soraluce A, Maynar J, Sánchez-Izquierdo JÁ, et al. Population pharmacokinetics of piperacillin and tazobactam in critically ill patients undergoing continuous renal replacement therapy: application to pharmacokinetic/pharmacodynamic analysis. J Antimicrob Chemother 2014;69:180-9.

30. Fish DN, Teitelbaum I, Abraham E. Pharmacokinetics and pharmacodynamics of imipenem during continuous renal replacement therapy in critically ill patients. Antimicrob Agents Chemother 2005;49:2421-8.

31. Cotton A, Franklin BD, Brett S, Holmes A. Using imipenem and cilastatin during continuous renal replacement therapy. Pharm World Sci 2005;27:371-5.

32. Mistry GC, Majumdar AK, Swan S, Sica D, Fisher A, Xu Y, et al. Pharmacokinetics of ertapenem in patients with varying degrees of renal insufficiency and in patients on hemodialysis. J Clin Pharmacol 2006; $46: 1128-38$. 
33. Hidaka $S$, Goto K, Hagiwara S, Iwasaka H, Noguchi T. Doripenem pharmacokinetics in critically ill patients receiving continuous hemodiafiltration (CHDF). Yakugaku Zasshi;130:87-94.

34. Cirillo I, Vaccaro N, Balis D, Redman R, Matzke GR. Influence of continuous venovenous hemofiltration and continuous venovenous hemodiafiltration on the disposition of doripenem. Antimicrob Agents Chemother 2011;55:1187-93.

35. Isla A, Rodríguez-Gascón A, Trocóniz IF, Bueno L, Solinís MA, Maynar J, et al. Population pharmacokinetics of meropenem in critically ill patients undergoing continuous renal replacement therapy. Clin Pharmacokinet 2008; $47: 173-80$.

36. Meyer B, Kornek GV, Nikfardjam M, Karth GD, Heinz G, Locker GJ, Jaeger $\mathrm{W}$, et al. Multiple-dose pharmacokinetics of linezolid during continuous venovenous haemofiltration. J Antimicrob Chemother 2005;56:172-9.

37. Pea F, Viale P, Lugano M, Pavan F, Scudeller L, Della Rocca G, et al. Linezolid disposition after standard dosages in critically ill patients undergoing continuous venovenous hemofiltration: a report of 2 cases. AmJ Kidney Dis 2004;44:1097-102.

38. Roux AF, Moirot E, Delhotal B, Leroy JA, Bonmarchand GP, Humbert G, et al. Metronidazole kinetics in patients with acute renal failure on dialysis: a cumulative study. Clin Pharmacol Ther 1984;36:363-8.

39. Kreeft JH, Ogilvie RI, Dufresne LR. Metronidazole kinetics in dialysis patients. Surgery 1983;93:149-53.

40. Fuhrmann V, Schenk P, Mittermayer C, El Menyawi I, Ratheiser K, Thalhammer F. Single-dose pharmacokinetics of ofloxacin during continuous venovenous hemofiltration in critical care patients. Am J Kidney Dis 2003;42:310-4.

41. Choi G, Gomersall CD, Lipman J, Wong A, Joynt GM, Leung P, et al. The effect of adsorption, filter material and point of dilution on antibiotic elimination by haemofiltration an in vitro study of levofloxacin. Int J Antimicrob Agents 2004;24:468-72.

42. Ronco C, Crepaldi C, Brendolan A, Bordoni V, D’Intini V, Bellomo R. Performance of DIAPES filters in CRRT. Contrib Nephrol 2003;138:144-52.

43. Debruyne D, Ryckelynck JP. Clinical pharmacokinetics of fluconazole. Clin Pharmacokinet 1993;24:10-27

44. Berl T, Wilner KD, Gardner M, Hansen RA, Farmer B, Baris BA, et al. Pharmacokinetics of fluconazole in renal failure. J Am Soc Nephrol 1995; 6:242-247

45. Pittrow L, Penk A. Dosage adjustment of fluconazole during continuous renal replacement therapy (CAVH, CVVH, CAVHD, CVVHD). Mycoses 1999;42:17-9.

46. Yagasaki K, Gando S, Matsuda N, Kameue T, Ishitani T, Hirano T,et al. Pharmacokinetics and the most suitable dosing regimen of fluconazole in critically ill patients receiving continuous hemodiafiltration. Intensive Care Med 2003;29:1844-8.

47. Bergner R, Hoffmann M, Riedel KD, Mikus G, Henrich DM, Haefeli WE, et al. Fluconazole dosing in continuous veno-venous haemofiltration (CVVHF): need for a high daily dose of $800 \mathrm{mg}$. Nephrol Dial Transplant 2006;21:1019-23.

48. Scholz J, Schulz M, Steinfath M, Höver S, Bause H. Fluconazole is removed by continuous venovenous hemofiltration in a liver transplant patient. J Mol Med (Berl) 1995;73:145-7.

49. See comment in PubMed Commons belowMuhl E, Martens T, Iven H, Rob P, Bruch HP. Influence of continuous veno-venous haemodiafiltration and continuous veno-venous haemofiltration on the pharmacokinetics of fluconazole. Eur J Clin Pharmacol 2000;56:671-8.

50. Watt KM, Gonzalez D, Benjamin DK Jr, Brouwer KL, Wade KC, Capparelli E, et al. Fluconazole population pharmacokinetics and dosing for prevention and treatment of invasive Candidiasis in children supported with extracorporeal membrane oxygenation. Antimicrob Agents Chemother 2015;59:3935-43.

51. Kroh UF, Lennartz H, Edwards D, Stoeckel K. Pharmacokinetics of ceftriaxone in patients undergoing continuous veno-venous hemofiltration. J Clin Pharmacol 1996;36:1114-9.
52. Matzke GR, Frye RF, Joy MS, Palevsky PM. Determinants of ceftriaxone clearance by continuous venovenous hemofiltration and hemodialysis. Pharmacotherapy 2000;20:635-43.

53. Simon N, Dussol B, Sampol E, Purgus R, Brunet P, Lacarelle B, et al. Population pharmacokinetics of ceftriaxone and pharmacodynamic considerations in haemodialysed patients. Clin PharmacokinetSee comment in PubMed Commons below 2006;45:493-501.

54. Patel IH, Sugihara JG, Weinfeld RE, Wong EG, Siemsen AW, Berman SJ. Ceftriaxone pharmacokinetics in patients with various degrees of renal impairment. Antimicrob Agents Chemother. 1984;25:438-42.

55. Salama NN, Segal JH, Churchwell MD, Patel JH, Gao L, Heung M, et al. Single-dose daptomycin pharmacokinetics in chronic haemodialysis patients. Nephrol Dial Transplant 2010;25:1279-84.

56. Churchwell MD, Pasko DA, Mueller BA. Daptomycin clearance during modeled continuous renal replacement therapy. Blood Purif 2006;24:548-54.

57. Corti N, Rudiger A, Chiesa A, Marti I, Jetter A, Rentsch K, et al. Pharmacokinetics of daily daptomycin in critically ill patients undergoing continuous renal replacement therapy. Chemotherapy 2013;59:143-51.

58. Voriconazole package insert. In. New York, NY: Pfizer Pharmaceuticals, distributed by Roerig Division of Pfizer Inc; 2007 November.

59. Kiser TH, Fish DN, Aquilante CL, Rower JE, Wempe MF, MacLaren R, et al. Evaluation of sulfobutylether- $\beta$-cyclodextrin (SBECD) accumulation and voriconazole pharmacokinetics in critically ill patients undergoing continuous renal replacement therapy. Crit Care 2015;19:32.

60. Quintard H, Papy E, Massias L, Lasocki S, Arnaud P, Desmonts JM, et al.The pharmacokinetic profile of voriconazole during continuous highvolume venovenous hemofiltration in a critically ill patient. Ther Drug Monit 2008;30:117-9.

61. Honore PM, Jacobs R, Hendrickx I, De Waele E, Van Gorp V, Spapen HD. Continuous renal replacement therapy for safe and adequate voriconazole intravenous treatment: enough reason to be confident? Crit Care 2015;19:234

62. von Mach MA, Burhenne J, Weilemann LS. Accumulation of the solvent vehicle sulphobutylether beta cyclodextrin sodium in critically ill patients treated with intravenous voriconazole under renal replacement therapy. BMC Clin Pharmacol 2006;6:6.

63. Honore PM, Jacobs R, Hendrickx I, Bagshaw SM, Joannes-Boyau O, Boer W, et al. Prevention and treatment of sepsis-induced acute kidney injury: an update. Ann Intensive Care 2015;5:51.

64. Honoré PM, Jacobs R, Joannes-Boyau O, Lochy S, Boer W, De Waele E, et al. Continuous renal replacement therapy-related strategies to avoid colistin toxicity: a clinically orientated review. Blood Purif 2014;37:291-5.

65. Jamal JA, Mueller BA, Choi GY, Lipman J, Roberts JA. How can we ensure effective antibiotic dosing in critically ill patients receiving different types of renal replacement therapy? Diagn Microbiol Infect Dis 2015;82:92-103.

66. Honoré PM, Jacobs R, Joannes-Boyau O, Boer W, De Waele E, Van Gorp $\mathrm{V}$, et al. Continuous renal replacement therapy allows higher colistin dosing without increasing toxicity. J Transl Intern Med 2013;1:6-8.

67. Honore PM, Jacobs R, Joannes-Boyau O, De Regt J, De Waele E, van Gorp V, et al. Newly designed CRRT membranes for sepsis and SIRS--a pragmatic approach for bedside intensivists summarizing the more recent advances: a systematic structured review. ASAIO J 2013;59:99-106.

68. Honore PM, Spapen HD. Neutrophil gelatinase-associated lipocalin elimination by renal replacement therapy: minding the membrane ! Crit Care 2016;20:87

69. de Montmollin E, Bouadma L, Gault N, Mourvillier B, Mariotte E, Chemam S, et al. Predictors of insufficient amikacin peak concentration in critically ill patients receiving a $25 \mathrm{mg} / \mathrm{kg}$ total body weight regimen. Intensive Care Med. 2014;40:998-1005.

70. Beumier M, Roberts JA, Kabtouri H, Hites M, Cotton F, Wolff F, et al. A new regimen for continuous infusion of vancomycin during continuous renal replacement therapy. J Antimicrob Chemother 2013;68:2859-65. 
71. Honoré PM, Jacobs R, Joannes-Boyau O, Lochy S, Boer W, De Waele E, et al. Continuous renal replacement therapy-related strategies to avoid colistin toxicity: a clinically orientated review. Blood Purif 2014;37:291-5.

72. Brasseur A, Hites M, Roisin S, Cotton F, Vincent JL, De Backer D, et al. A high-dose aminoglycoside regimen combined with renal replacement therapy for the treatment of MDR pathogens: a proof-of-concept study. J Antimicrob Chemother 2016;71:1386-94.

73. Honore PM, Jacobs R, Hendrickx I, De Waele E, Van Gorp V, Spapen HD. Meropenem therapy in extracorporeal membrane oxygenation patients: an ongoing pharmacokinetic challenge. Crit Care 2015;19:263.

74. Boselli E, Breilh D, Rimmelé T, Guillaume C, Xuereb F, Saux MC, et al. Alveolar concentrations of piperacillin/tazobactam administered in continuous infusion to patients with ventilator-associated pneumonia. Crit Care Med. 2008;36:1500-6.
75. Layeux B, Taccone FS, Fagnoul D, Vincent JL, Jacobs F. Amikacin monotherapy for sepsis caused by panresistant Pseudomonas aeruginosa. Antimicrob Agents Chemother. 2010;54:4939-41.

76. Honore PM, Jacobs R, Lochy S, De Waele E, Van Gorp V, De Regt J, et al. Acute respiratory muscle weakness and apnea in a critically ill patient induced by colistin neurotoxicity: key potential role of hemoadsorp tion elimination during continuous veno venous hemofiltration. Int J Nephrol Renovasc Dis 2013;6:107-11.

77. Honore PM, Jacobs R, Waele ED, Gorp VV, Spapen HD. Colistin pharmacokinetics/pharmacodynamics and acute kidney injury: A difficult but reasonable marriage. Indian J Crit Care Med 2014;18:415-6.

How to cite this article: Breilh D, Honore PM, De Bels D, Roberts JA, Gordien JB, Fleureau C, et al. Pharmacokinetics and Pharmacodynamics of anti-infective agents during continuous venovenous hemofiltration in critically ill patients: Lessons learned from an ancillary study of the IVOIRE trial. J TransI Int Med 2019; 7: 155-69. 